\title{
PENERAPAN PENDEKATAN ILMIAH TERHADAP PRAKTIKUM FISIKA PESERTA DIDIK SMA NEGERI 21 MAKASSAR
}

*Sulhijrah Bola

Universitas Negeri Makassar

Sulhijrah.bola.s@gmail.com

Aisyah Azis

Universitas Negeri Makassar aisyah.azis@unm.ac.id

Ahmad Yani

Universitas Negeri Makassar a.yani@unm.ac.id

\footnotetext{
* Koresponden Author
}

\begin{abstract}
Abstrak - Penelitian ini adalah Pra Eksperimen, dengan desain One Shot Case Study yang bertujuan untuk mengetahui besar kemampuan praktikum fisika setelah diajar menggunakan pendekatan ilmiah pada peserta didik kelas X Negeri 21 Makassar Tahun Ajaran 2018/2019. Subyek penelitian ini yakni 33 peserta didik. Instrument yang digunakan dalam penelitian yakni tes praktikum fisika materi getaran harminik sederhana. Hasil analisis deskriptif menunjukkan skor ratarata praktikum fisika peserta didik kelas X SMA Negeri 21 Makassar setelah diajar menggunakan pendekatan ilmiah sebesar 73,48\% berada pada kategori tinggi dan skor rata-rata setiap indikator yaitu menginterpretasi data 80,09\%, menerapkan konsep 65,91\%, memprediksi $75,15 \%$ semuanya berada pada kategori tinggi.
\end{abstract}

Kata Kunci : pendekatan ilmiah, praktikum, fisika, deskriptif

Abstract - Research this is a pre-experiment, with design of One Shot Case Studywhich aims to know the great ability of practicum physics after being taught to use approach to science on the participant students class X MIPA 2 SMA Negeri 21 Makassar Academic Year 2017/2018. Subyek research is that 33 participants students. Instruments are used in descriptive analysis results show that average score of practicum physics in grade X MIPA 2 students of SMA 21 Makassar in the academic year 2017/2018 after being taught using a scientific approach is 73,48 \%, it is good category and the average score of each indicator is interpreting the data $80,05 \%$, applying the concept of $65,91 \%$, predicting $75,15 \%$, all of in the high category.

Keywords: scientific approach, physics practicum, physics, descriptive 


\section{A. PENDAHULUAN}

Dalam rangka peningkatan mutu pendidikan, khususnya untuk memacu penguasaan ilmu pengetahuan dan teknologi maka proses belajar mengajar perlu disempurnakan dan ditingkatkan. Upaya tersebut hampir mencakup semua komponen pendidikan seperti pembaruan kurikulum, peningkatan kualitas guru, pengadaan buku pelajaran, sarana prasarana belajar, proses belajar mengajar, penyempuranaan sistem penilaian, manajemen pendidikan, penataan organisasi dan usahausaha lainnya yang berkaitan dengan penigkatan mutu pendidikan.

Pada kurikulum 2013, proses pembelajaran untuk semua jenjang dilaksanakan menggunakan pendekatan saintifik (Scientifik Approach) melalui kegiatan mengamati, menanya, menalar, mencoba dan membentuk jejaring (Permendikbud Nomor 65 Tahun 2013). Pembelajaran fisika itu sendiri merupakan serangkaian proses penyelidikan ilmiah (scientific) untuk mempelajari karakter, gejala, dan peristiwa yang terjadi atau terkandung dalam benda mati atau bemda yang tidak dapat melakukan pengembangan diri. Penyelidikan tersebut dimaksudkan untuk menumbuhkan kemampuan berfikir, berkeja, dan bersikap ilmiah serta berkomunikasi sebagai salah satu aspek penting kecakapan hidup (Permendiknas Nomor 24 Tahun 2006).

Menurut pandangan teori belajar Piaget (Mundilarto, 2002) yang menyatakan bahwa peserta didik dapat melakukan aktivitas observasi, praktikum, diskusi dan lain-lain untuk dapat membangun pengetahuannya sendiri. Implikasinya pada pembelajaran fisika ialah pendidik harus memberikan kesempatan kepada peserta didik untuk aktif berpikir dalam berbagai kegiatan pembelajaran, salah satunya praktikum fisika.

Dalam pembelajaran praktikum fisika peserta didik mampu membangun konsep serta bermakna dengan cara menghubungkan hasil pengamatan dengan teori yang sudah dimiliki sebelumnya, peserta didik juga dapat memecahkan permasalahan-masalahan sains dengan cara melakukan kegiatan praktikum di laboratorium. (Raina Vovianti, 2011). Laboratorium dan jenis peralatannya merupakan sarana dan prasarana penting untuk menunjang proses pembelajaran di sekolah, hal ini dikemukakan pada PP nomor 19 tahun 2005 tentang Standar Nasional Pendidikan pasal 42 ayat (2) serta pasal 43 ayat (1) dan ayat (2).

Hasil wawancara dengan guru menunjukkan bahwa pengajaran fisika di SMAN 21 Makassar biasanya pendidik membuka pembelajaran dengan memberi motivasi awal pentingnya belajar fisika dikaitkan dengan aplikasi sederhana dalam kehidupan sehari-hari sesuai materi yang diajarkan. Setelah itu pendidik memberi materi kepada peserta didik lalu disertai beberapa contoh soal dan latihan soal agar peserta didik lebih paham mengenai materi fisika yang diajarkan tersebut. Adapun mengenai pelaksanaan pembelajaran fisika menggunakan praktikum belum sepenuhnya menjadi prioritas utama karena dengan pertimbangan waktu mengajar yang terbatas. Sehingga, peserta didik kurang aktif dalam pembelajaran fisika. 
Berdasarkan gambaran di atas, maka peneliti sangat tertarik untuk mengadakan penelitian dengan judul "Penerapan Pendekatan Ilmiah Terhadap Praktikum Fisika Peserta Didik Kelas X MIPA 2 SMA 21 Makassar". Berdasarkan msaalah tersebut, maka tujuan dari penelitian ini adalah untuk mengetahui besar praktikum fisika setelah diajar dengan menggunakan pendekatan ilmiah pada peserta didik kelas X MIPA 2 SMAN 21 Makassar tahun ajaran 2017/2018.

Menurut (Daryanto, 2014) pembelajaran melalui saintifik adalah proses pembelajaran yang dirancang sedemikian rupa agar peserta didik secara aktif mengonstruksi konsep, hukum, atau prinsip melalui tahapan-tahapan mengamati (untuk mengindetifikasi atau menemukan masalah), merumuskan masalah, mengajukan atau merumuskan hipotesis, mengumpulkan data dengan berbagai teknik, menganalisis data, menarik kesimpulan, dan mengomunikasikan konsep, hukum, atau prinsip yang ditentukan.

Tujuan pembelajaran dengan pendekatan saintifik didasarkan pada keunggulan pendekatan tersebut, antara lain: (1) meningkatkan kemampuan intelek, khususnya kemampuan berpikir tingkat tinggi, (2) untuk membentuk kemampuan siswa dalam menyelesaikan suatu masalah secara sistematik, (3) terciptanya kondisi pembelajaran dimana siswa merasa bahwa belajar itu merupakan suatu kebutuhan, (4) diperolehnya hasil belajar yang tinggi, (5) untuk melatih peserta didik dalam mengkomunikasikan ide-ide, khususnya dalam menulis artikel ilmiah, dan (6) untuk mengembangkan karakter peserta didik (Machin, 2014).

Berdasarkan beberapa referensi di atas, maka peneliti menyimpulkan bahwa pendekatan ilmiah atau saintifik merupakan sebuah pendekatan dengan melibatkan peserta didik secara aktif untik menemukan atau membuktikan suatu konsep melalui beberapa proses, yakni mengamati, menanya, mengumpulkan informasi, mengolah informasi, mengomunikasikan dan menarik kesimpulan.

Pratikum berasal dari kata praktik yang artinya pelaksanaan secara nyata apa yang disebut dalam teori. Sedangkan pratikum adalah bagian dari pengajaran yang bertujuan agar siswa mendapat kesempatan untuk menguji dan melaksanakan di keadaan nyata, apa yang diperoleh dari teori dan pelajaran praktik (KBBI, 2001). Menurut Sudirman (1992), metode praktikum adalah cara penyajian pelajaran kepada siswa untuk melakukan percobaan dengan mengalami dan membuktikan sesuatu yang dipelajari. Hal ini didukung pula oleh Winatapura (1998) yang menyatakan bahwa metode praktikum adalah suatu cara penyajian yang disusun secara aktif untuk mengalami dan membuktikan sendiri tentang apa yang dipelajarinya.

Metode praktikum atau disebut juga kegiatan laboratorium yang dimaksudkan di sini adalah pengalaman belajar yang memungkinkan peserta didik berinteraksi dengan material sampai kepada observasi fenomena (Adisendjaja, 2008). Alat praktikum dalam proses pembelajaran IPA memegang peranan penting sebagai alat bantu untuk menciptakan proses belajar efektif.

Menurut Djajadisastra 1982, dalam Widya, 2016 ada tiga langkah utama yang perlu dilakukan dalam melakukan praktikum fisika, yaitu langkah persiapan, langkah pelaksanaan, dan tindak lanjut metode praktikum. 
Langkah persiapan diperlukan untuk memperkecil kelemahan-kelemahan atau kegagalankegagalan yang dapat muncul. Kegiatan yang dapat dilakukan dalam langkah persiapan antara lain menetapkan judul dan tujuan praktikum, mempersiapkan alat dan bahan yang diperlukan, mempersiapkan tempat praktikum, mempertimbangkan jumlah siswa dengan jumlah alat yang tersedia dan kapasitas tempat praktikum, mempersiapkan tata tertib dan disiplin selama praktikum, serta membuat petunjuk dan langkah-langkah praktikum.

Pada langkah pelaksanaan praktikum, siswa melakukan kegiatan praktikum sesuai dengan petunjuk dan langkah-langkah yang telah dibuat pada tahap persiapan praktikum. Langkah-langkah yang dibuat disesuaikan dengan materi pembelajaran yang akan dipraktikumkan. Kegiatan siswa dalam pelaksanaan praktikum adalah mengobservasi (mengamati) percobaan atau mempediksi, mencatat data, menganalisisdata (menginterpretasi data), menjawab pertanyaan, menyimpulkan hasil praktikum (menerapkan konsep), dan mengomunikasikan hasil praktikum. Sedangkan guru dalam pelaksanaan praktikum adalah mengawasi proses praktikum yang sedang dilakukan oleh siswa, baik secara menyeluruh maupun perkelompok. Setelah praktikum dilaksanakan, kegiatan guru selanjutnya adalah melakukan tindak lanjut kepada siswa dengan cara meminta siswa membersihkan dan menyimpan peralatan yang digunakan, mendiskusikan masalah-masalah yang ditemukan selama praktikum, membuat laporan hasil praktikum, meminta perwakilan siswa untuk mempresentasikan hasil laporan yang telah diperoleh dan dibuat selama kegiatan praktikum berlangsung. Sehingga berdasarkan penjelasan di atas dapat menyimpulkan bahwa indikator praktikum fisika yang dijelaskan adalah menginterpretasi data, menerapkan konsep dan memprediksi.

\section{B. METODE}

Jenis penelitian ini adalah penelitian Pra Eksperiment dengan desain One Shot Case Study. Adapun subyek penelitian ini adalah 33 peserta didik. Penelitian ini terdiri dari 2 variabel yaitu variabel bebas (pendekatan ilmiah) dan variabel tidak bebas (praktikum fisika). Adapun defenisi variabel pendekatan ilmiah suatu pendekatan yang dirancang sedemikian rupa agar peserta didik secara aktif mengamati, menanya, mengumpulkan informasi, mengasosiasikan, menyimpulkan dan mengkomunikasikan. Praktikum fisika adalah skor yang diperoleh peserta didik setelah diberikan tes praktikum fisika dalam bentuk pilihan ganda dengan indikator menginterpretasi data, menerapkan konsep dan memprediksi.

Kriteria skor praktikum fisika peserta didik diadaptasi dari buku Riduwan dengan merujuk pada kriteria interpretasi skor dimana disesuaikan dengan skor tertinggi ideal dan skor terendah ideal dengan rentang 0-22. Sehingga diperoleh interval skor yang pada dilihat pada Tabel 1 dimana pengkategorian tersebut memberikan gambaran tentang tingkatan pencapaian peserta didik sebagai berikut: 
Tabel 1. Pengkategorian Skor Praktikum Fisika

\begin{tabular}{ll}
\hline Persentase & Kriteria \\
$81-100$ & Sangat Tinggi \\
$61-80$ & Tinggi \\
$41-60$ & Cukup \\
$21-40$ & Rendah \\
$0-20$ & Sangat Rendah
\end{tabular}

\section{HASIL DAN PEMBAHASAN}

Gambaran skor praktikum fisika peserta didik kelas X MIPA 2 SMAN 21 Makassar diperoleh nilai rata-rata $(x)$, standar deviasi $(S)$, dan varians $\left(S^{2}\right)$ seperti yang terlihat pada tabel 2.

Tabel 2. Skor praktikum fisika

\begin{tabular}{cc} 
Statistik & $\begin{array}{l}\text { Nilai } \\
\text { statistik }\end{array}$ \\
\hline Ukuran sampel (n) & 33 \\
\hline Skor tertinggi ideal & 20 \\
\hline Skor terendah ideal & 0 \\
\hline Skor tertinggi & 18 \\
\hline Skor terendah & 11 \\
\hline Rentang skor & 7 \\
\hline Skor rata-rata & 14,70 \\
\hline Varians & 3,41 \\
\hline Standar deviasi & 1,85
\end{tabular}

Untuk pengkategorian skor praktikum fisika peserta didik Kelas X MIPA 2 SMAN 21 Makassar dapat dilihat pada tabel 3 berikut:

Tabel 3. Persentase dan Kategori Skor Praktikum Fisika Peserta Didik Kelas X MIPA 2

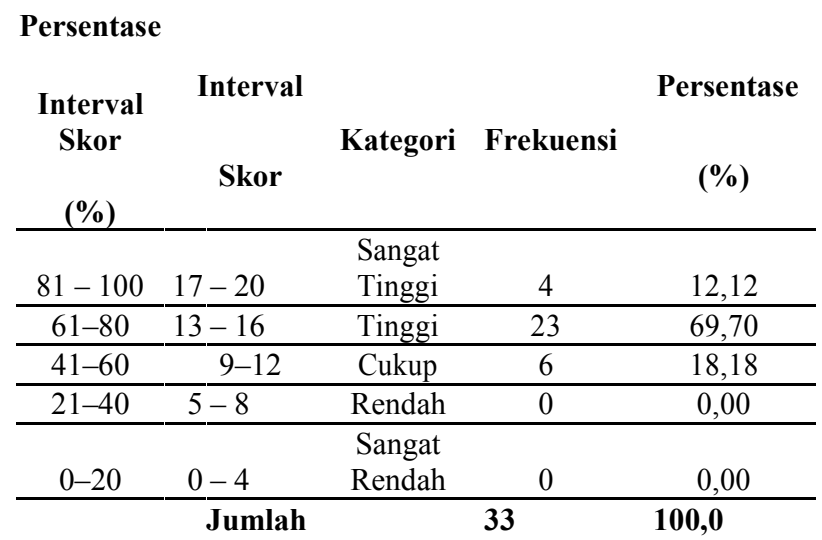

Selanjutnya praktikum fisika peserta didik Kelas X MIPA 2 SMAN 21 Makassar pada masing-masing indikator dapat dilihat pada tabel 4 sebagai berikut: 
Tabel 4. Gambaran Praktikum Fisika Peserta Didik pada Setiap Indikator

\begin{tabular}{ccccc}
$\begin{array}{c}\text { Indikator } \\
\text { Praktikum }\end{array}$ & Skor & \multicolumn{2}{c}{$\begin{array}{l}\text { Persent } \\
\text { ase }\end{array}$} \\
& \multicolumn{2}{c}{ Skor } & \\
Fisika & Rata- & & $\begin{array}{c}\text { Kateg } \\
\text { ori }\end{array}$ \\
& rdeal & $\mathbf{( \% )}$ & \\
\hline $\begin{array}{c}\text { Menginterpretasi } \\
\text { data }\end{array}$ & 5,61 & 7 & 80,09 & Tinggi \\
\hline $\begin{array}{c}\text { Menerapkan } \\
\text { Konsep }\end{array}$ & 5,27 & 8 & 65,91 & Tinggi \\
\hline Memprediksi & 3,76 & 5 & 75,15 & Tinggi
\end{tabular}

Penelitian ini merupakan Pra-Experiment dengan desain penelitian One Shot Case Study. Peneltitan ini bertujuan untuk mendeskripsikan praktikum fisika peserta didik kelas X MIPA 7 SMA Negeri 21 Makassar dalam pembelajaran fisika dengan menggunakan pendekatan ilmiah pada materi getaran harmonis sederhana. Dalam hal ini, praktikum fisika yang dimaksud adalah skor yang dicapai oleh peserta didik setelah melalui proses pembelajaran fisika dengan menggunakan pendekatan ilmiah. Penelitian ini dilakukan dengan mengambil satu kelas sebagai subyek penelitian untuk diajar menggunakan pendekatan ilmiah. Hasil penelitian ini menunjukkan bahwa dengan digunakannya pendekatan ilmiah diperoleh gambaran praktikum fisika dengan standar deviasi sebesar 1,85 . Nilai standar deviasi yang diperoleh yaitu 1,85 yang nilainya lebih kecil dibandingkan skor rata-rata yaitu 14,70 sehingga merupakan representasi yang baik bagi keseluruhan data yang dalam hal ini peserta didik. Adapun kategori praktikum fisika peserta didik terbesar yaitu pada kategori baik dengan persentase $69,70 \%$. Pengkategorian ini berdasarkan pada skor praktikum fisika peserta didik. Hal ini terlihat dari distribusi frekuensi pengkategorian skor keterampilan Praktikum Fisika pada Tabel 3.

Dari hasil analisis tiap indikator dapat diperoleh bahwa praktikum fisika peserta didik terbesar yaitu pada indikator pertama menginterpretasi persentase $80,09 \%$, selanjutnya indikator ketiga memprediksi persentase $75,15 \%$, dan terakhir diikuti indikator kedua yaitu menginterpretasi persentase 65,91\%, (Tabel 4).

Berdasarkan uraian diatas, maka dapat dikemukakan bahwa pembelajaran fisika dengan menerapkan pendekatan ilmiah memiliki fungsi positif dalam memaksimalkan praktikum fisika, khususnya pada peserta didik kelas X MIPA 2 SMA Negeri 21 Makassar tahun ajaran 2017/2018.

\section{.D. SIMPULAN}

Kesimpulan yang diperoleh dari hasil penelitian ini bahwa skor rata-rata praktikum fisika peserta didik kelas X MIPA 2 SMA Negeri 21 Makassar Tahun ajaran 2017/2018 setelah diajar menggunakan pendekatan ilmiah sebesar $73,48 \%$ berada pada kategori baik dan skor rata-rata setiap indikator yaitu menginterpretasi data 80,09\% menerapkan konsep 65,91\%, memprediksi $75,15 \%$. 


\section{DAFTAR RUJUKAN}

Gregory, R. J. (2015). Psychological Testing (History, Principles, and Aplications Seventh Edition). England: Person Education Limited.

Adisendjaja, Y.H. 2008. Handout Pembelajaran Sains untuk Pendidikan Dasar. Jurusan Pendidikan Biologi FPMIPA UPI, Bandung.

Agus Wahyudi, Elmi Mahzum, Zahara Rita, 2017. Perbandingan Pembelajaran Metode Praktikum Berbasis Keterampilan Proses dan Metode Praktikum Biasa Terhadap Prestasi Belajar Siswa. Jurnal Ilmiah Mahasiswa Vol. 2 No 1, Unsyiah.

Daryanto, 2014. Pendekatan Pembelajaran Saintifik Kurikulum 2013. Yogyakarta:

Gaya Media. Departemen Pendidikan Nasional, Peraturan Pemerintah Republik Indonesia Nomor 19 tahun 2005 tentang Standar Nasional Pendidikan, Jakarta: Departemen Pendidikan Nasional, 2005.

Gregory,Robert.(2014).PsychologicalTesting:History,Principles, andApplications.Boston:

Allyn and Bacon

KBBI, 2001. Kamus Besar Bahasa Indonesia. Jakarta: Balai Pustaka

Machin, A. (2014). Implementasi Pendekatan Saintifik, Penanaman Karakter, dan Konservasi pada pembelajaran Materi Pertumbuhan. Jurnal Pendidikan IPA Indonesia, 3, 28-35.

Marjan, J., Aryana, I.P., \& Setiawan, I. N. (2014). Pengaruh Pembelajaran Pendekatan Saintifik Terhadap Hasil Belajar Biologi dan Keterampilan Proses Sains Siswa MA Mu'allimat NW Pancor Selong Kabupaten Lombok Timur Nusa Tenggara Barat. EJournal Program Pascasarjana Universitas Pendidikan Ganesha, 1-12.

Permendikbud, 2013. Jurnal Lampiran Menteri Pendidikan dan Kebudayaan Republik Indonesia Nomor 65 Tahun 2013 tentang Standar Proses Pendidikan Dasar dan Menengah. Jakarta.

Riduwan, 2017. Metode Penelitian Pendidikan. Bandung: Alfabeta

Sudjana, A. (2005). Metode Statistik. Bandung: Tarsito

Sugiyono, 2015. Metode Penelitian Pendidikan Pendekatan Kuantitatif, Kualitatif dan R\&D. 20 ed. Bandung: Alfabeta. 